\title{
RESEARCH INTO CAUSES OF HEAT TRANSFER RESISTANCE FALLOFF OF ENCLOSURE STRUCTURES
}

\author{
Pavel Trubaev \\ Institute of Power Engineering, Information Technologies \\ and Operating Systems \\ BSTU named after V. G. Shukov \\ Belgorod, Russia \\ trubaev@gmail.com
}

\begin{abstract}
The work studies the results of the heat exchange process simulation through the bond of various types, the measurement of heat transfer resistance of the enclosure structure of operated buildings in Moscow, Stary Oskol and Belgorod. In addition, it studies the measurement results of the heat transfer resistance of enclosure structures under laboratory conditions to compare their actual burning characteristics and design values. The authors verified the cause of the mismatch between the actual heat transfer resistance and the design value in the proximity of enclosure structures. It is made clear that it is a structural design that exercises the main influence upon the actual heat transfer resistance of enclosure structures in relation to the design value, not the materials employed. It is found that the enclosure structures that have a heat insulation layer, set under construction, have the actual heat transfer resistance that is lower than the design value. The enclosure structures, made as a brick or block work and assembled under plant conditions, correspond to the stated properties by their heat-shield performance.
\end{abstract}

Keywords - heat transfer resistance, enclosure structures, heat insulation, energy efficiency, operated buildings

\section{INTRODUCTION}

The heat transfer resistance of the enclosure structures is the main characteristic of the building heat insulation $[1,2]$. Its lowest target value is stated by construction regulations. When the heat insulation of buildings and facilities is designed, the heat transfer parameter estimates of building materials and products $[3,4]$ are used. The actual values of the material thermal conductivity in operated buildings can dramatically differ from design values, resulting from the increased humidity and civil structure wear due to the quality problem of constructional materials and work [5-7].

The work studies the results of the heat exchange process simulation through the bond of various types, the measurement of heat transfer resistance of the enclosure structure of operated buildings in Moscow, Stary Oskol and Belgorod. In addition, it studies the measurement results of the heat transfer resistance of enclosure structures under laboratory conditions to compare their actual burning characteristics and design values.

The article was prepared within development program of the Flagship Regional University on the basis of Belgorod State Technological University named after V.G. Shukhov

\author{
Pavel Tarasyuk \\ Institute of Power Engineering, Information Technologies \\ and Operating Systems \\ BSTU named after V. G. Shukov \\ Belgorod, Russia \\ tarasyuk88@mail.ru
}

\section{LITERATURE REVIEW}

A number of works presented the in-situ studies of thermal characteristics of enclosure structures.

Work [8] shows that the actual specific heating characteristic of operated buildings in Moscow is much higher that the design value (fig. 1). The authors explain this fact by the remarkable heat oversupply, in other words, the supply of an excess heat amount on the premises. However, an increase in heat consumption several-fold cannot be explained only by the heat oversupply, as in this case the temperature on the premises would be higher than the design values by the similar magnitude.

The degradation of the building energy performance can be caused by the non-conformance of design and actual thermal characteristics of enclosure structures [9].

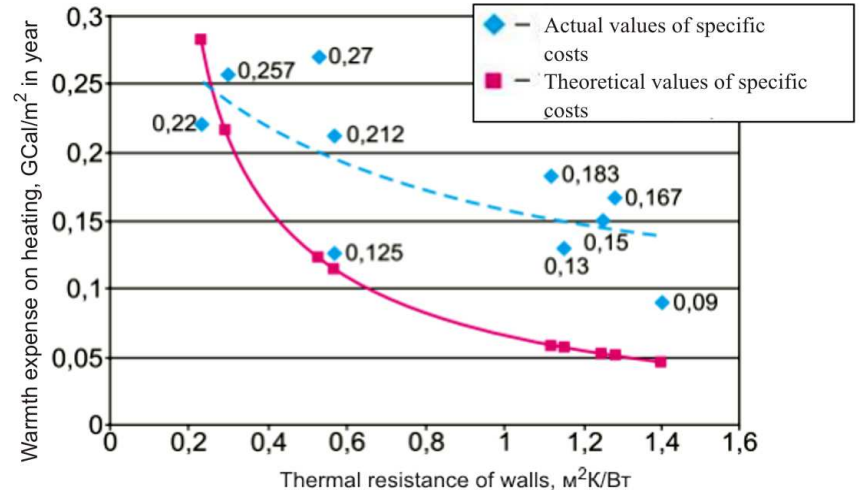

Fig. 1. Ratio of theoretical and actual heat consumption for house heating [8]

In work [10], N.S. Guryanov studied in-situ the thermal characteristics of outside walls for buildings operated in the Republic of Sakha (Yakutia), analyzed their design and actual values of the heat transfer resistance and its change over the building operating cycle.

Analysis of the thermal characteristic degradation of enclosure structures in terms of their type and operating cycle cited in work [10] is given in tables 1 and 2.

Analysis of the in-situ studies allowed identifying that the thermal characteristics of enclosure structures decrease by the 
exponential dependence exponent during fledging years (10 years) of the building operation.

For the 10-year buildings, the decrease in the heat transfer resistance is of the form of the power dependence. Hereafter, the resistance decreases linearly (fig. 2).

Based on the stated dynamics of the heat transfer resistance decrease of the multilayered enclosing structures as time goes by, N.S. Guryanov suggested using reduction coefficient $\mathrm{k}_{\mathrm{D}}$ that defines more exactly their design value changing while in building operation.

Therefore, the outside wall heat insulation decrease can be described as:

$$
R_{\mathrm{d}}=\left\{\begin{array}{l}
R_{\mathrm{n}} \cdot \mathrm{e}^{-0,0707 T_{\mathrm{n}}, 0 \leq T_{\mathrm{n}} \leq 10 ;} \\
-6.7 \cdot 10^{-3} T_{\mathrm{n}}+1.177, T_{\mathrm{n}}>10
\end{array}\right.
$$

where $T_{\mathrm{n}}$ - building service time, years, $R_{\mathrm{d}}-$ design heat transfer resistance, $\mathrm{M}^{2} \cdot{ }^{\circ} \mathrm{C} / \mathrm{W}$ att, $R_{\mathrm{n}}-$ nominal heat transfer resistance, $\mathrm{M}^{2} \cdot{ }^{\circ} \mathrm{C} / \mathrm{W}$ att.

TABLE I. CHANGE IN THERMANL INSULATION PARAMETERS OF ENCLOSURE STRUCTURES

\begin{tabular}{|l|c|c|}
\hline \multicolumn{1}{|c|}{ Enclosure structure material } & $\begin{array}{c}\text { Service time, } \\
\text { years }\end{array}$ & $\begin{array}{c}\text { Heat insulation } \\
\text { parameter decrease } \\
\text { compared to design } \\
\text { parameters, \% }\end{array}$ \\
\hline $\begin{array}{l}\text { Small stone outside walls with } \\
\text { urethane foam insulation }\end{array}$ & 10 & 59.1 \\
\hline $\begin{array}{l}\text { Panelized outside walls with miner- } \\
\text { al wool heat insulation }\end{array}$ & $17-21$ & 47.5 \\
\hline $\begin{array}{l}\text { Large panel walls with polystyrene } \\
\text { foam insulation }\end{array}$ & 10 & 49.4 \\
\hline Large-block wall structures & $8-9$ & 27 \\
\hline Assembled from timber strips & 21 & 4.2 \\
\hline Brick outside walls & $20-24$ & 0.2 \\
\hline $\begin{array}{l}\text { Three-layer small stone outside } \\
\text { walls with heat insulation }\end{array}$ & 1 & 47.5 \\
\hline
\end{tabular}

TABLE II. COMPARISON OF DESIGN $R_{0 \text { (calc) }}^{\mathrm{n}}$ AND ACTUAL $R_{0(\mathrm{f})}^{n}$ PARAMETERS OF THE OUTSIDE WALL HEAT INSULATION [10]

\begin{tabular}{|c|c|c|c|c|}
\hline № & $\begin{array}{c}\text { Address } \\
(\text { YrBlt })\end{array}$ & $\begin{array}{c}R_{0 \text { (calc) }}^{\mathrm{n}} \\
\mathrm{m}^{2} \mathrm{~K} / \mathrm{Watt}\end{array}$ & $\begin{array}{c}R_{0 \text { (f) }}^{n}, \\
\mathrm{~m}^{2} \mathrm{~K} / \mathrm{Watt}\end{array}$ & $\Delta, \%$ \\
\hline \multicolumn{4}{|c|}{ Brick walls, $\delta=770 \mathrm{~mm}$} \\
\hline 1 & 2, Lenin Str (1978) & 1.14 & 1.15 & 101.2 \\
\hline 2 & $\begin{array}{c}\text { 14, Kravchenko Str } \\
(1982)\end{array}$ & 1.12 & 1.14 & 101.8 \\
\hline \multicolumn{4}{|c|}{ Large-block walls, $\delta=770 \mathrm{~mm}$} \\
\hline 3 & $\begin{array}{c}\text { 37/3. Churapchinskaya } \\
\text { Str (1993) }\end{array}$ & 1.36 & 0.99 & 75.9 \\
\hline 4 & $\begin{array}{c}\text { 24. Yu. Yakutskaya Str } \\
\text { (1994) }\end{array}$ & 1.03 & \\
\hline
\end{tabular}

\begin{tabular}{|c|c|c|c|c|}
\hline 5 & $\begin{array}{l}\text { 12. Ostrovskogo Str } \\
\text { (1993) }\end{array}$ & & 0.92 & 67.7 \\
\hline \multicolumn{5}{|c|}{ Walls assembled from timber strips, $\delta=180 \mathrm{~mm}$} \\
\hline 6 & $\begin{array}{l}\text { 81. Serebryany Bor } \\
\text { (1981) }\end{array}$ & 1.32 & 1.27 & 95.8 \\
\hline \multicolumn{5}{|c|}{$\begin{array}{l}\text { Small stone walls with urethane foam insulation } \\
\qquad\left(\delta_{\mathrm{w}}=600 \mathrm{~mm}, \delta_{\mathrm{u}}=100 \mathrm{~mm}\right)\end{array}$} \\
\hline 7 & 4. Sosnovaya Str (1992) & 2.8 & 1.15 & 40.9 \\
\hline \multicolumn{5}{|c|}{$\begin{array}{l}\text { Large panel walls with polystyrene foam insulation } \\
\qquad\left(\delta_{\mathrm{w}}=240 \mathrm{~mm}, \delta_{\mathrm{u}}=160 \mathrm{~mm} \text {. }\right)\end{array}$} \\
\hline 8 & $\begin{array}{l}\text { 6/2. Druzhby Narodov Str } \\
\text { (1992) }\end{array}$ & \multirow{3}{*}{2.47} & 1.26 & 50.93 \\
\hline 9 & 6. Bochkareva Str (1991) & & 1.17 & 47.6 \\
\hline 10 & $\begin{array}{l}\text { 33. Druzhby Narodov Str } \\
\text { (1984) }\end{array}$ & & 1.05 & 42.5 \\
\hline 11 & 5. Mira Av (1992) & 2.25 & 1.13 & 50.3 \\
\hline \multicolumn{5}{|c|}{$\begin{array}{l}\text { Large panel walls with polystyrene foam insulation } \\
\left(\delta_{\mathrm{w}}=150 \mathrm{~mm}, \delta_{\mathrm{u}}=100 \mathrm{~mm}\right) \text {, outside walls with mineral wool heat insulation } \\
\left(\delta_{\mathrm{u}}=80 \mathrm{~mm}\right) \text { in } 2001\end{array}$} \\
\hline 12 & $\begin{array}{l}\text { Boarding school. Iengra } \\
\text { (1989) }\end{array}$ & 3.4 & 1.06 & 31.1 \\
\hline \multicolumn{5}{|c|}{$\begin{array}{l}\text { Wood panelized walls with mineral wool heat insulation } \\
\qquad\left(\delta_{\mathrm{w}}=130 \mathrm{~mm}, \delta_{\mathrm{u}}=100-125 \mathrm{~mm}\right)\end{array}$} \\
\hline 13 & $\begin{array}{l}\text { 180. Serebryany Bor } \\
\text { (1981) }\end{array}$ & \multirow{2}{*}{2.31} & 1.07 & 46.1 \\
\hline 14 & $\begin{array}{l}\text { 110. Serebryany Bor } \\
\text { (1985) }\end{array}$ & & 1.24 & 53.7 \\
\hline 15 & $\begin{array}{l}\text { 77. Serebryany Bor } \\
\text { (1985) }\end{array}$ & \multirow{2}{*}{2.65} & 1.45 & 54.7 \\
\hline 16 & 103. Serebryany Bor & & 1.47 & 55.5 \\
\hline
\end{tabular}

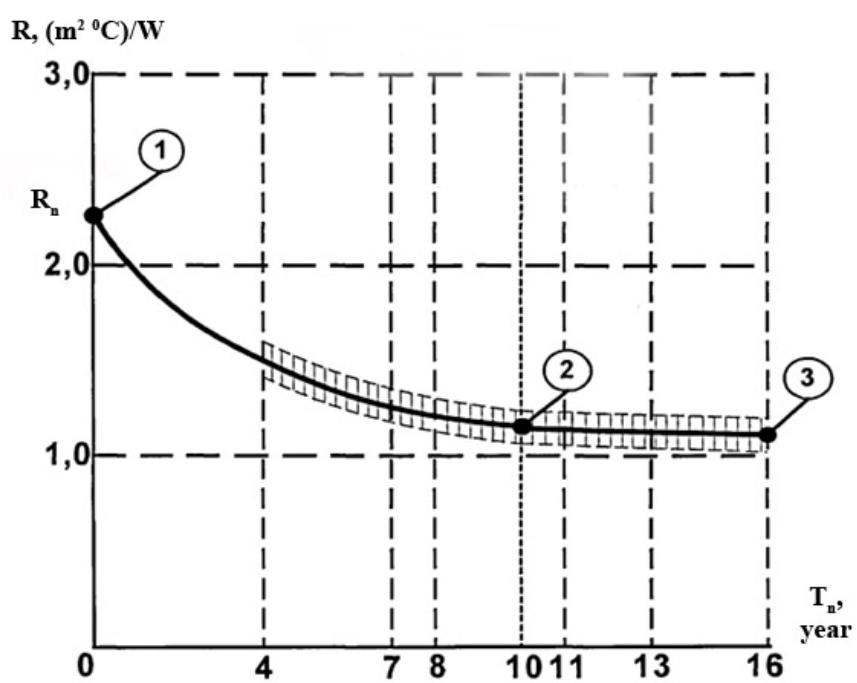

Fig. 2. Heat transfer resistance relationaship of enclosure structures when time goes by [10] 
The deviation of the obtained experimental function does not exceed $\pm 10 \%$.

Therefore, the highest decrease in the heat transfer resistance can be seen for enclosure structures with a heat insulation layer.

The papers $[11,12]$ of D.A. Mikheev for standard multiapartment buildings, operated in Krasnoyarsk and its suburbs, cite the temperature distribution estimate for enclosure structure external faces. The author demonstrated that the actual temperature distribution obtained with the thermovision survey allows determining design features and defects of enclosure structures.

Enclosure structures with nonhomogeneous fields have the highest difference in surface temperature.

In paper [13], S.N. Begday identified under semicommercial conditions the solar radiation influence on the heat transfer resistance of enclosure structures provided with mineral wool and extruded foam polystyrene heat insulation. It was stated that the calculation accuracy of the heat transfer resistance can be increased by $26 \%$ when the non-linear models are used. It shows that the heat transfer rate in enclosure structures is nonuniform.

\section{METHODOLOGY}

The mathematic simulation was carried out with the heat transfer two-dimensional analysis THERM program based on the finite-element method that allows determining the heat transfer resistance for irregular-shaped civil structures.

The heat transfer resistance for operated building walls was measured with ITP-MG4.03/10 "Potok" during the heating period.

Under laboratory conditions, the heat transfer resistance was measured in a climatic test chamber.

\section{MAIN PART}

\section{A. Joint size influence on the heat transfer resistance of} expended clay block laying

The heat insulation of enclosure structures is determined first and foremost by their heat transfer resistance. However, there is a range of difficulties to determine this parameter that are connected to the high equipment cost, the necessity in specific weather conditions, the human factor etc.

The heat transfer analysis carried out with the mathematic or computer simulation allows assessing the energy efficiency of the product (wall, window, floor, roof and door) and the pattern in-situ temperature that enables to solve the problems of condensation, product material moisture and its imperviousness.

The authors used the heat transfer two-dimensional analysis THERM program based on the finite-element method that allows determining the heat transfer resistance for irregularshaped civil structures.

The program graphical user interface allows drawing the structural cross-sections of constructions or their components for the further thermal calculations. To design the cross- sections, the authors use the imported file tracking at DXF or bitmap format, or a direct drawing of the structure geometry in specified size.

Every cross-section is presented by a set of polygons. The user defines material properties for every polygon and environment conditions surrounding the analyzed structure, and determines the boundary conditions surrounding the crosssection. When the model is determined, the further calculation steps (development of the computation mesh and heat transfer analysis) are carried out automatically. The user can study the calculation results in different formats including the heat transfer resistance, the heat conductivity coefficient, isothermal lines, heat-flux vectors and in-situ temperatures $[14,15]$.

The heat transfer resistance was studied in terms of LECA blocks joint with the sand-cement mortar with the heat conductivity coefficient equal to $0.76 \mathrm{Watt} /(\mathrm{m} \cdot \mathrm{K})]$. The outside temperature in wintertime $\left(-20^{\circ} \mathrm{C}\right)$ and the room temperature $\left(22^{\circ} \mathrm{C}\right)$ are the boundary conditions of the heat transfer simulation.

In the course of work, the authors analyzed the influence of the heat conductivity coefficient, the block laying method and the sand-cement mortar depth on the heat transfer resistance.

Three specimens of diverse density were selected to study the heat transfer resistance of LECA block walls. The heat conductivity coefficients of these materials are shown in table 3 .

TABLE III. LECA HEAT CONDUCTIVITY COEFFICIENTS

\begin{tabular}{|c|c|}
\hline Density $\rho_{0}, \mathrm{~kg} / \mathrm{m}^{3}$ & $\begin{array}{c}\text { Heat conductivity coefficient } \lambda, \\
\text { Watt } /(\mathrm{m} \cdot \mathrm{K})\end{array}$ \\
\hline 500 & 0.17 \\
\hline 800 & 0.24 \\
\hline 1200 & 0.44 \\
\hline
\end{tabular}

Fig. 3 displays various LECA block-laying methods. The block size for every model is equal and corresponds to the standard parameters of $390 \times 190 \times 188$. As it is a $2 \mathrm{D}$ model, the specimen width $(190 \mathrm{~mm})$ and length $(390 \mathrm{~mm})$ are the characteristic dimensions.

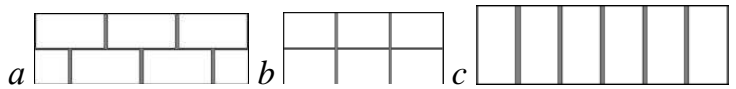

Fig. 3. LECA block-laying methods: $a$ - version $1 ; b$ - cersion 2 ; $c$ - version 3

The sand-cement mortar depth between the blocks plays a significant role in the heat transfer process and the wall heat transfer resistance. Fig. 4 shows the results of the heat transfer resistance based on all parameter interaction. 


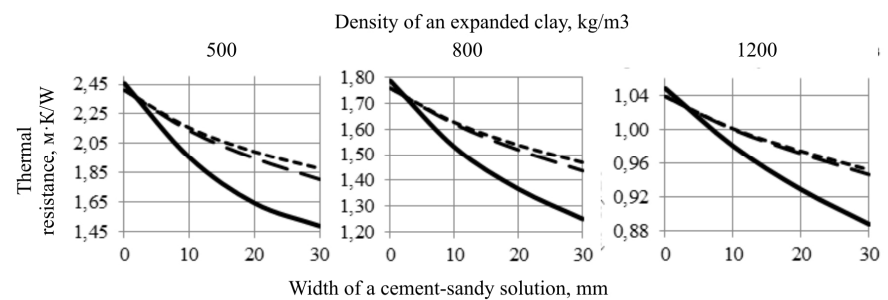

Fig. 4. Dependence of the heat transfer resistance of the LECA block wall of a diverse density and the sand-ccement mortar depth. LECA block-laying methods (fig. 1 ): - - - - version $1 ;----$ version $2 ;--$ version 3

The sand-cement mortar depth influence the heat transfer resistance for the first version of the LECA block laying. The heat transfer resistance errors are given in table 4.

TABLE IV. HEAT TRANSFER RESISTANCE CHANGE AS THE SAND-CEMENT MORTAR DEPTH INCREASES FROM 0 MM TO 30 MM

\begin{tabular}{|l|l|l|l|}
\hline \multirow{2}{*}{ Material } & \multicolumn{4}{|l|}{ Error in terms of the block laying method, \% } \\
\cline { 3 - 5 } & Version 1 & Version 2 & Version 3 \\
\hline $\begin{array}{l}\text { Expanded clay aggregate } \\
500 \mathrm{~kg} / \mathrm{m}^{3}\end{array}$ & 39 & 35 & 22 \\
\hline $\begin{array}{l}\text { Expanded clay aggregate } \\
800 \mathrm{~kg} / \mathrm{m}^{3}\end{array}$ & 30 & 18 & 16 \\
\hline $\begin{array}{l}\text { Expanded clay aggregate } \\
1200 \mathrm{~kg} / \mathrm{m}^{3}\end{array}$ & 15 & 9 & 8 \\
\hline
\end{tabular}

THERM program can calculate not only the heat transfer resistance but also:

- isothermal lines (fig. 5);

- heat-flux vectors;

- color heat-flux lines (fig. 6);

- temperatures (in-situ and daily average, maximum and minimum).

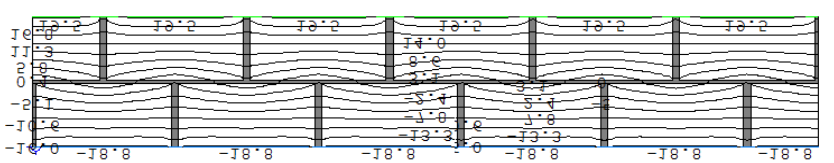

Fig. 5. Temperature distribution by isothermal lines inside the simulated wall (version1)

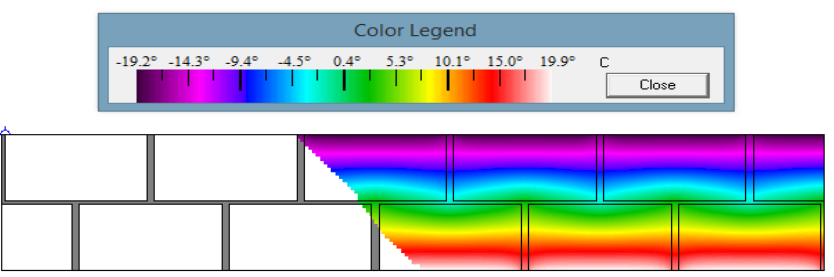

Fig. 6. Color heat-flux lines inside the wall (version 1)

Conclusions. The joint thickness influences the heat transfer resistance of the bond. This influence is in process when the low heat conductivity coefficient blocks are laid. Therefore, the building and construction work quality and material characteristics influence the thermal properties of enclosure structures.

\section{B. Thermal characteristic measurement under laboratory conditions}

Experimental measurements of the heat transfer resistance under laboratory conditions were carried out for 32 types of construction materials and various versions of enclosure structure layer-to-layer overlay.

The obtained data allowed identifying a set of dependences for design, and actual heat transfer resistance deviations of their values and enclosure structure characteristics, determined for enclosure structures, were segregated by the specified parameters. Table 3 shows the ratio between the actual (measured) heat transfer resistance and the design one for diverse types of enclosure structures. As it can be seen, the solid-web structures have the lowest deviation of the actual resistance from the design one; the heat insulation enclosure structures have the highest deviation.

TABLE V. DECREASE IN THE HEAT TRANSFER RESISTANCE OF ENCLOSURE STRUCTURES OF VARIOUS TYPES

\begin{tabular}{|l|l|l|}
\hline Enclosure structure type & $\begin{array}{l}\text { Number of } \\
\text { experiments }\end{array}$ & $\begin{array}{l}\text { Ratio between the } \\
\text { actual value and the } \\
\text { design one, \% }\end{array}$ \\
\hline $\begin{array}{l}\text { Brick work from solid bricks or } \\
\text { blocks }\end{array}$ & 13 & $74 \%$ \\
\hline $\begin{array}{l}\text { Brick work from hollow bricks or } \\
\text { blocks }\end{array}$ & 10 & $61 \%$ \\
\hline $\begin{array}{l}\text { Foamed or expanded concrete } \\
\text { enclosure structure }\end{array}$ & 13 & $65 \%$ \\
\hline $\begin{array}{l}\text { Mineral wool insulation enclosure } \\
\text { structure }\end{array}$ & 3 & $65 \%$ \\
\hline $\begin{array}{l}\text { Polymer insulation enclosure } \\
\text { structure }\end{array}$ & 26 & $51 \%$ \\
\hline
\end{tabular}

Fig. 5 shows the ratio between the actual heat transfer resistance and the design resistance for enclosure structures segregated by the design heat transfer resistance value and the number of layers. The enclosure structures with a low and high heat transfer resistance have the highest relative deviation. It can be explained by the fact that the walls with a low heat transfer resistance are influenced a lot by structural defects and heat transfer non-homogeneities (bond, heatinsulating board joints etc.). If the walls have a high heat transfer resistance the biggest part of which is a polymer insulation resistance, the decrease in the actual heat transfer resistance can be explained by the mismatch of thermal insulation properties and declared values, and by the significant decrease in thermal properties caused by the insulation bonding technique. The lowest ratio between the actual and design heat transfer resistance for two-layered constructions can be explained by the same reason. 
a)

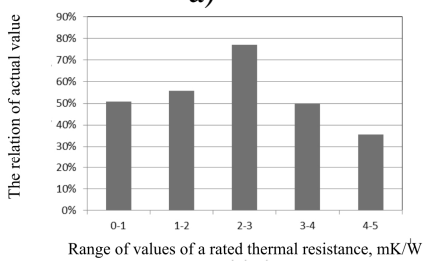

b)

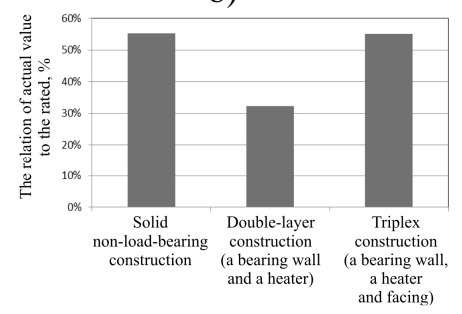

Fig. 7. Decrease in the heat transfer resistance due to: a) design heat transfer resistance; b) numbers of layers

Table 4 shows the influence of element size that constitute the enclosure structures on the heat transfer resistance decrease. The received data showed that this influence is not found.

TABLE VI. DEVIATION OF THE DESIGN HEAT TRANSFER RESISTANCE AND THE ACTUAL RESISTANCE IN TERMS OF THE ENCLOSURE STRUCTURE TYPE

\begin{tabular}{|l|l|l|}
\hline Enclosure structure type & $\begin{array}{l}\text { Number } \\
\text { experiments }\end{array}$ & $\begin{array}{l}\text { Ratio between the } \\
\text { actual value and the } \\
\text { design one, \% }\end{array}$ \\
\hline Solid-web structure & 46 & $58 \%$ \\
\hline Large-scale element (block) & 95 & $62 \%$ \\
\hline Small-scale element (brick) & 13 & $71 \%$ \\
\hline
\end{tabular}

The authors analyzed the influence of certain materials on the reduction value of the ratio between the actual rand design resistance. To do that, they determined the deviation values for various types of materials found in the studied specimens (table 5). As it can be seen, the highest deviation of the design heat transfer resistance and the actual resistance is observed for specimens with the insulation.

Unlike the rendered data, the difference in obtained data is negligible for various materials. Therefore, it is the structural design not the applied materials that has the main influence on the actual heat transfer resistance decrease.

TABLE VII. DEVIATION OF THE DESIGN HEAT TRANSFER RESISTANCE AND THE ACTUAL RESISTANCE IN TERMS OF THE MATERIL TYPE

\begin{tabular}{|l|l|l|}
\hline Material type of enclosure structure & $\begin{array}{l}\text { Number of } \\
\text { experiments }\end{array}$ & $\begin{array}{l}\text { Ratio between the } \\
\text { actual value and the } \\
\text { design one, \% }\end{array}$ \\
\hline Insulation & 34 & $56 \%$ \\
\hline Brick work from solid bricks & 12 & $69 \%$ \\
\hline Expanded aggregate cocrete & 78 & $61 \%$ \\
\hline Brick work from hollow bricks & 17 & $64 \%$ \\
\hline Honeycomb concrete & 13 & $71 \%$ \\
\hline
\end{tabular}

Thus, the selection of an optimal structural design of enclosure structures will allow one to achieve the maximum degree of energy saving. It is important for individual conduit that develops actively in Belgorod region as the low-rise buildings have a higher building compactness ratio than that of the high-rise buildings, and the elementary heating discharge is higher in the similar structural design of enclosure structures

and the energy excess demand is higher if they have some defects.

\section{In-situ measurements of thermal properties}

Eighteen residential and public buildings built before the revolution of massive site development and of modern energyefficient design were studied [16]. The actual values of the heat transfer resistance of enclosure structures made of brick, blocks or panels produced under plant conditions correspond to their design values. The deviation of the design and actual heat transfer resistance is caused by the building wear and the building and construction work quality. It is lower than 0.1$0.2 \mathrm{~m}^{2} \cdot \mathrm{K} / \mathrm{Watt}$. Therefore, for the multilayer buildings the with mineral wool insulation laid under construction, the actual heat transfer resistance is lower than the design one and the deviation is $0.36 \ldots 2.91 \mathrm{~m}^{2} \cdot \mathrm{K} / \mathrm{W}$ att.

\section{CONCLUSION}

The actual values of the heat transfer resistance of homogeneous enclosure structures or multilayer panels produced under plant conditions correspond to the design value. For the multilayer buildings with the mineral wool insulation laid under construction, the actual heat transfer resistance is $70-80 \%$ of the design value.

\section{SUMMARY}

The structural design influences the decrease of the actual heat transfer resistance of enclosure structures compared to the design values.

The enclosure structures that have an insulation layer laid under construction have the actual heat transfer resistance that is lower than the design one. The brick or block enclosure structures, and the structures assembled under plant conditions correspond to their design values by their thermal properties.

The highest deviation of the heat transfer resistance and its design value can be observed for insulation wall structures. The insulation building method and the vapor control barrier mounting location influence the heat transfer resistance. Some manufacturers claim an underestimated material thermal conductivity that is characterized by far lower parameters of the heat transfer resistance for enclosure structures than those that are designed with high insulation properties.

\section{References}

[1] Ju.A. Tabunshikov, M.M. Brodach, N.V. Shilkin Energy-efficient buildings, Moscow: Avok-Press, 2003.

[2] E.G Malyavina, Heatlosses of the building, Moscow: AVOK, 2007

[3] L.A. Kushhev, G.L. Dronova, Ways to decrease energy consumption in housing, Bulletin of BSTU named after V. G. Shukhov, No 2, pp. 24-25, 2008.

[4] A.V. Kuznetsov, Assessment of thermal qualities of monolithic design buildings in St. Petersburg, Conf. Construction of thermophysics and energy efficient design of building structures, SPb: Izd-vo Politehn. unta, pp: 35-43, 2011.

[5] V.G. Gagarin, Thermal-physical properties of modern enclosure structures of multi-storey buildings, II Conf. Construction of thermophysics and energy efficient design of building structures (St. Petersburg), pp: 33-44, 2009. 
[6] E.G. Malyavina, Construction thermophysics and issues of modern building insulation, AVOK, No 1, pp. 4-7, 2009.

[7] N.S. Guryanov, Assessment and thermal reliability of the operated building outside walls, Cand. diss., Nizhny Novgorod, 2003

[8] E.G. Gasho, S.A. Kozlov, V.P. Kozhevnikov, Some ways to increase the heat supply efficiency: regulation or autonomous heating?, Heating news, No 2, pp. 17-22, 2007.

[9] A.S. Gorshkov, V.I. Livchak, History, evolution and development of normative requirements to enclosure structures, Construction of unique buildings, No 3 (30), pp. 7-37, 2015.

[10] N.S. Guryanov, Assessment and thermal reliability of of the operated building outside walls, Cand. diss., Nizhny Novgorod, 2003.

[11] D.A. Mikheev, E.S. Ermilova, Homogeniety of enclosure structures, XXV conf, Krasnoyarsk: Sibirian federal district., pp. 273-276, 2007.
[12] D.A. Mikheev, Increase in thermal efficiency of outside wall barriers based on thermovision studies, Cand. diss, Krasnoyarsk, 2010.

[13] S.N. Begday, Increase in thermal efficiency of one-storey buildings with a heliocollector, Cand. diss, Volgograd, 2008.

[14] C. Huizenga, D. K. Arasteh, E. Finlayson, R. Mitchell, B. Griffith and D. Curcija, "Teaching Students About Two-Dimensional Heat Transfer Effects in Buildings, Building Components, Equipment, and Appliances Using THERM 2.0.”, ASHRAE Transactions, No 105 (2), pp. 488-502, 1999.

[15] THERM 6.3/WINDOW 6.3. NFRC Simulation Manual, Lawrence Berkeley National Laboratory, December 2011.

[16] P.N. Tarasyuk, D.A. Vashenko, P.A. Trubaev, V.V. Radchenko, Analysis of the heat transfer resistance of enclosure structures of different types by results of tool measurements, Bulletin of BSTU named after V. G. Shukhov, No 2, pp. 142-14, 2015. 